\title{
P8-022
}

\section{Sjogren 症候群が疑われた竹節状声帯の一例}

$\bigcirc$ 花井俊一朗 ${ }^{1,2}$, 永谷勝也 ${ }^{1}$, 秋山陽一郎 ${ }^{1}$, 石澤彩子 ${ }^{1}$, 長嶋孝夫 ${ }^{1}$, 佐藤健夫 ${ }^{1}$, 岩本雅弘 ${ }^{1}$, 签田清次 ${ }^{1}$ ( ${ }^{1}$ 自治医科大学内科学講座 アレルギ一膠原病学部門, ${ }^{2}$ 山梨大学医学部 内科学講座第 3 教室)

【症例】 27 歳の女性【主訴】嗄声と咽頭痛【現病歴】約 1 年前から嗄声と咽頭痛とを自覚していた。耳 鼻咽喉科を受診し，喉頭ファイバースコピーで竹節状声带を指摘された。血液検査で抗核抗体が陽性 であったため基礎疾患として膠原病が疑われ，プレドニゾロン $30 \mathrm{mg}$ を開始されたが改善を認めず, 当科を紹介受診し, 精査のため入院した. 【入院後経過】入院時の検査で抗核抗体 1280 倍, リウマト イド因子, 抗 SS-A 抗体および抗 SS-B 抗体が陽性であり, Sjogren 症候群が疑われた。ガムテストお よびシルマーテストは陰性, 口唇腺生検では軽度のリンパ球浸潤を認め, 診断基準は満たさなかった が，プレドニゾロン投与により唾液腺炎が改善した可能性を考え, 臨床的にSjogren 症候群を疑った。 【考察】竹節状声带は 1993 年に本邦から寶迫らが全身性エリテマトーデス（SLE）患者に認められた特 異な喉頭所見として初めて報告した.SLEなどの自己免疫性疾患に合併する病変として複数の報告が あるが, 病態は不明で確立された治療法はない。自己免疫性疾患に伴う特徵的な声带病変である竹節 状声带では, 嗄声が唯一の初発症状のこともあり, 原因として自己免疫性疾患の存在を念頭に置くこ とが重要であると考える。【結語】Sjogren 症候群が疑われた竹節状声带の一例を経験したので, 文献 的考察を含めて報告する. 